\title{
1 Dietary polyphenols bind to potato cells and cellular components
}

3 Laura G. Gómez-Mascaraque ${ }^{1}$, Sushil Dhital ${ }^{2}$, Amparo López-Rubio ${ }^{1}$, Michael J.

4 Gidley $^{2 *}$

5

$6{ }^{1}$ Food Quality and Preservation Department, IATA-CSIC, Avda. Agustin Escardino 7,

746980 Paterna, Valencia, Spain.

$8 \quad{ }^{2}$ ARC Centre of Excellence in Plant Cell Walls, Centre for Nutrition and Food Sciences,

9 Queensland Alliance for Agriculture and Food Innovation, The University of

10 Queensland, St Lucia, Qld 4072, Australia.

11

12 *Corresponding author: Tel.: +61 73365 2145; fax: +61 733651177

13 E-mail address: m.gidley@uq.edu.au (M. J. Gidley)

\footnotetext{
${ }^{1}$ Abbreviations:

CLSM: Confocal laser scanning microscopy

FT-IR: Fourier transform infrared spectroscopy

ATR: Attenuated total reflectance

PBS: phosphate buffered saline
} 


\section{ABSTRACT}

The ability of phenolic compounds to bind to dietary polysaccharides such as starch and plant cell wall components impacts their nutritional value. Here, we report interactions between potato cells and three different phenolic compounds $(+)$-catechin, phloridzin and vanillic acid. The binding interactions of the phenolic compounds with intact potato cells, as well as disrupted cells, cooked cells, isolated cell walls and starch granules was explored varying polyphenol concentration, $\mathrm{pH}$ and incubation time. Results showed that binding capacity depends on the type of phenolic compound $((+)$-catechin $>$ phloridzin $>$ vanillic acid) as well as the type of substrate, to a maximum of $\sim 50 \mu \mathrm{mol} / \mathrm{g}$ (dry weight). The observed differences $(\mathrm{p}<0.05)$ were ascribed to the amount and accessibility of potential binding sites in both the phenolic compounds and the polysaccharides. Remarkably, polyphenols could penetrate intact cells and bind the starch within them, suggesting their potential as delivery vehicles, whose loading capacity more than doubled after cooking.

\section{KEYWORDS}

Phenolic; cell wall; starch; plant cell; binding; polysaccharide.

\section{CHEMICAL COMPOUNDS STUDIED IN THIS ARTICLE}

(+)-Catechin (PubChem CID: 9064); Phloridzin (PubChem CID: 6072); Vanillic acid (PubChem CID: 8468). 


\section{Introduction}

The application of phenolic compounds as functional ingredients is widely studied (Gómez-Mascaraque, Lagarón, \& López-Rubio, 2015; Han et al., 2011; Kumpoun, Motomura, \& Nishizawa, 2015; Shi et al., 2005; Sun-Waterhouse et al., 2009). In a complex food system, interactions between these bioactive compounds and the food matrix may affect the quality of polyphenol-rich food products, as these interactions impact both the bioavailability and bioactivity of the phenolic compounds (Jakobek, 2015; Le Bourvellec \& Renard, 2012).

Recent studies using in-vitro systems suggest that nutritionally-significant amounts of phenolic compounds can bind to plant cell walls and cell wall analogues (Padayachee et al., 2012a, 2012b; Phan et al., 2015). These bound phenolics are, therefore, delivered to the large intestine where both dietary fiber and polyphenols have been shown to exert positive effects on microbial populations, thereby promoting health benefits (Aleixandre \& Miguel, 2016; Conlon \& Topping, 2016; Kaulmann \& Bohn, 2016; Klinder et al., 2016; Moreno-Indias et al., 2016). This and other practical implications have led to an increase in the research attention paid to the binding of phenolic compounds to plant cell walls (Bautista-Ortín, Cano-Lechuga, Ruiz-García, \& Gómez-Plaza, 2014; Le Bourvellec, Guyot, \& Renard, 2004; Renard, Baron, Guyot, \& Drilleau, 2001). Apart from cell walls, the interactions between phenolic compounds and starch, another major plant-derived carbohydrate in human diet (Han, Choi, Kim, Kim, \& Baik, 2015; Liu et al., 2016), may affect not only the nutritional properties of the phenolic compounds but also the processability as well as enzymic susceptibility of starches (Zhu, 2015).

It is generally agreed that the binding of polyphenols to macromolecules, and specifically polysaccharides, is mainly mediated by hydrogen bonds and hydrophobic 
interactions (Le Bourvellec et al., 2004; Le Bourvellec \& Renard, 2012; Renard et al., 2001), although the exact mechanisms are not fully understood yet. Covalent bonding between phenolic compounds and polysaccharides has been reported too (Rustioni, Fiori, \& Failla, 2014). The occurrence of ionic interactions has also been proposed for charged molecules, such as the binding of anthocyanins to pectins (Padayachee et al., 2012a). Most works report that the binding capacity increases with the molecular weight of the phenolic compounds (Bindon, Smith, \& Kennedy, 2010; Le Bourvellec, Bouchet, \& Renard, 2005; Le Bourvellec et al., 2004; Le Bourvellec \& Renard, 2005; Renard et al., 2001), although other factors such as the stereochemistry or the degree of galloylation of polyphenols have been suggested to have an effect on the absorption capacity (Le Bourvellec et al., 2004).

Regarding the associations with plant cell walls, i.e. complex polysaccharide networks, some studies highlight the role of specific polysaccharide composition on their binding capacity towards polyphenols. For instance, procyanidins and anthocyanins were found to preferentially bind to pectins as compared to other cell wall components (Le Bourvellec et al., 2005; Le Bourvellec, Guyot, \& Renard, 2009; Padayachee et al., 2012a), while phenolic acids bound faster to cellulose than to cellulose-pectin composites (Padayachee et al., 2012b). The complex porous structure and distribution of hydrophilic/hydrophobic domains within the cell walls has also been observed to play an important role in their absorption capacity (Le Bourvellec \& Renard, 2005; Renard et al., 2001). On the other hand, starch, compared to pectin and cellulose, has shown an intermediate affinity for procyanidins (Le Bourvellec et al., 2005).

Both starch and dietary fiber are major components of plant cells in e.g. cereals, legumes, bananas and tubers, and food processing frequently involves tissue disruption and cellular breakage, making both components readily available for interaction with 
polyphenols. However, many plant-derived foods are also consumed without major tissue disruption and cell breakage, and not all cells are ruptured during mastication, as the size of the average plant cell (of the order of $100 \mu \mathrm{m}$ ) is smaller than that of e.g. chewed vegetables pieces (Peyron, Mishellany, \& Woda, 2004). Hence, the interactions between polyphenols and intact plant cells are relevant to the nutritional functionality of foods, but little research attention has been paid to it yet.

In this manuscript, we report the binding of polyphenols to different potato cell components (i.e. cell walls and starch granules), as well as intact and broken cells, with the aim of elucidating the interactions taking place in this model food system. The cells from potato tubers were selected in this work as a model due to the ease of isolation of

starch, cell wall and cells from both raw and cooked tissues. Three molecules featuring diverse origins and different molecular structures and sizes (i.e. $(+)$-catechin, phloridzin and vanillic acid) were used as representative food phenolic compounds. In view of the obtained results, the potential for intact cells, with or without cooking, to act as encapsulation vehicles for phenolic compounds was also discussed.

\section{Materials and Methods}

\subsection{Materials}

Sebago cultivar potato tubers were purchased from a local supermarket and used as such for isolation of potato cells and cell components as described in Sections 2.2 and 2.3. Vanillic acid, phloridzin dihydrate, $(+)$-catechin hydrate, sodium azide, hydrochloric acid $(\mathrm{HCl}, 37 \%)$, sodium hydroxide $(\mathrm{NaOH})$, dimethyl sulfoxide (DMSO), ethanol and phosphate buffered saline (PBS) tablets were purchased from Sigma-Aldrich 
(Australia). Reagents for total starch determination were supplied by Megazyme International (Wicklow, Ireland).

\subsection{Isolation of potato cells}

Potato cells were isolated under mild conditions to minimise cellular damage. Cell detachment was achieved by successive treatment with mild acid and alkali solutions in order to remove pectin from middle lamella between cells (Aguilera, Cadoche, López, \& Gutierrez, 2001; Kugimiya, 1990). In brief, approximately $5 \mathrm{~g}$ of peeled potatoes were cut into cubes $(\sim 5 \mathrm{~mm})^{3}$, introduced into $50 \mathrm{~mL}$ tubes and immersed in $40 \mathrm{~mL}$ of $0.05 \mathrm{M}$ hydrochloric acid. The tubes were incubated at $100 \mathrm{rpm}$ for 6 hours at room temperature on a rocking shaker (MS-NRK, Major Science, Taiwan). The potato cubes were then washed 3 times with distilled water and incubated in $40 \mathrm{~mL}$ of $0.025 \mathrm{M}$ sodium hydroxide overnight. The resulting detached cells were thoroughly washed with running tap water on a stack of 250,175 and $90 \mu \mathrm{m}$ sieves. The isolated and predominantly intact cells (confirmed by microscopy, see Section 2.4.1) retained on the $90 \mu \mathrm{m}$ sieve were collected and stored in PBS buffer with $0.02 \%$ sodium azide under refrigeration until further use.

In order to assess the impact of the intactness of the cells on their binding affinity for the phenolic compounds, 'broken cells' samples were also generated by an overnight intense magnetic agitation of the intact cells, consequently disrupting them (confirmed by microscopy, see Section 2.4.1) as reported by (Dhital, Bhattarai, Gorham, \& Gidley, 2016) for legumes cells.

\subsection{Isolation of cell walls and starch granules}


Potato cell walls and starch granules were isolated by mechanical disruption of cells followed by selective sieving. For this purpose, potato tubers were peeled, cut into pieces and gently blended with excess water using a kitchen blender. The obtained blend was sieved and the filtrate containing the $<90 \mu \mathrm{m}$ fraction (starch granules) was collected and decanted. After several washing (with distilled water) and decanting steps, the starch granules were vacuum dried at room temperature. The $>300 \mu \mathrm{m}$ fraction retained on the biggest sieve was introduced again in the blender and homogenized with excess water, this time at the maximum intensity. The cell walls fraction was collected on a $150 \mu \mathrm{m}$ sieve after thoroughly washing with distilled water. Microscopic observations showed that some intact cells were still present in the collected fraction at that stage, so complete breakage of cells was accomplished by intense agitation for 2 days with magnetic stirrer bars in the presence of $0.02 \%$ sodium azide (Dhital et al., 2016). Complete removal of starch granules from the cell walls fraction was confirmed by microscopy after sieving. Cell walls were then thoroughly washed with distilled water and vacuum dried at room temperature.

\subsection{Characterisation of potato cells and cell components}

\subsubsection{Confocal laser scanning microscopy (CLSM)}

Potato cells and cell components were observed by CLSM using a LSM 700 microscope (Zeiss, Jena, Germany), both before and after conducting the binding assays. For fluorescence images capture, a $405 \mathrm{~nm}$ laser was used for excitation and emissions between 400 and $487 \mathrm{~nm}$ were collected. Objectives of 10x and 20x were used.

\subsubsection{Fourier transform infrared spectroscopy (FT-IR)}


FT-IR spectra were collected in attenuated total reflectance (ATR) mode using a Perkin Elmer Spectrum 100 spectrometer coupled to a Universal ATR sampling accessory. The spectra were obtained in the range $4000-650 \mathrm{~cm}^{-1}$ by averaging 32 scans at $2 \mathrm{~cm}^{-1}$ resolution.

\subsubsection{Total starch analysis}

The starch content of the potato cells was determined using the total starch Megazyme assay kit (K-TSTA 08/16, Megazyme International, Wicklow, Ireland), based on the AOAC Method 996.11 and AACC Method 76-13.01, and following the instructions given by the supplier. The cells were broken by intense agitation with magnetic stirrer bars overnight prior to analysis, to ensure complete access of the enzymes to starch (Dhital et al., 2016).

\subsection{Standard phenolic solutions}

0.25-3.0 $\mathrm{mM}$ solutions of the phenolic compounds were freshly prepared prior to use by dissolving them in phosphate buffered saline solution (PBS, $\mathrm{pH}=7.4)$ in the presence of $0.02 \%$ sodium azide. Brief mild heating was applied to dissolve phloridzin in the aqueous buffer.

\subsection{Polyphenol binding assays}

Binding assays were conducted following a method adapted from (Padayachee et al., 2012a) and (Phan et al., 2015). Briefly, ca. $20 \mathrm{mg}$ (expressed as dry weight) of substrate (i.e. potato cells, starch or cell walls) were incubated in $5 \mathrm{~mL}$ of phenolic solutions in a 
$15 \mathrm{~mL}$ Falcon tube completely wrapped with aluminium foil with shaking at $100 \mathrm{rpm}$ for $2 \mathrm{~h}$ on an orbital shaker at room temperature. Control samples in the absence of substrate, and blanks in the absence of phenolic compounds, were simultaneously incubated under the same conditions. Samples were then centrifuged at $4000 \mathrm{~g}$ (or $200 \mathrm{~g}$ in the case of intact cells to prevent breakage) and their absorbance at their $\lambda_{\max }(278$ $\mathrm{nm}$ for $(+)$-catechin, $285 \mathrm{~nm}$ for vanillic acid and $246 \mathrm{~nm}$ for phloridzin) was measured using a UV-1700 Pharma Spec UV-Vis spectrophotometer (Shimadzu, Japan), after dilution as required. The concentration of free (unbound) phenolic compounds in each sample after the assay was determined based on external standard curves $\left(R^{2} \geq 0.9998\right)$, and the amount of bound phenolic compounds was calculated according to Eq. 1. Results were obtained from independent triplicates.

Bound $(\%)=\frac{\text { Amount of phenolics in control }- \text { Amount of phenolics in sample }}{\text { Dry mass of cells or cell component }} \cdot 100 \quad$ Eq.

\subsection{Binding kinetics}

Binding assays were also conducted after different incubation periods using the method described in Section 2.6, to ascertain the relative binding rates to the different potato cell derived substrates. For this purpose, $250 \mu \mathrm{L}$ aliquots were sampled at different times of incubation (up to 6 hours) and the amount of bound phenolic compounds at each time period was calculated according to Eq. 1 .

\subsection{Effect of $\mathrm{pH}$ on the binding extent}


Binding assays were also conducted at $\mathrm{pH}=3$ (representing gastric $\mathrm{pH}$ (Minekus et al., 2014)) to ascertain the effect of $\mathrm{pH}$ on the binding of phenolic compounds to potato cells and cell components. For this purpose, the PBS buffer was replaced by a $0.001 \mathrm{~N}$ $\mathrm{HCl}$ solution and the assays were conducted following the procedure described in Section 2.6 for a concentration of phenolic compounds of $2 \mathrm{mM}$. The absorbance values in this medium were determined at $278 \mathrm{~nm}$ for (+)-catechin, $292 \mathrm{~nm}$ for vanillic acid and $283 \mathrm{~nm}$ for phloridzin (standard curves with $\mathrm{R}^{2} \geq 0.9999$ ).

\subsection{Effect of cooking on the binding extent}

In order to assess the impact of cooking on the affinity of potato cells for the phenolic compounds, 'cooked potato cells' were isolated by boiling potato cubes for $15 \mathrm{~min}$, and selectively sieving the boiled potato cells as described in Section 2.2. by gently pressing the cooked potato through the sieves in excess water. The cells were resuspended in PBS buffer in the presence of $0.02 \%$ sodium azide. Their binding to the phenolic compounds $(2 \mathrm{mM})$ was studied following the procedure in Section 2.6.

\subsection{Statistical analysis}

IBM SPSS Statistics software (v.23) (IBM Corp., USA) was used to perform the statistical analysis of the data. The significance of the differences observed between samples was assessed through two-sided t-tests at $\mathrm{p}<0.05$. For multiple comparisons, the p-values were adjusted using the Bonferroni correction. 


\section{Results and discussion}

\subsection{Isolation of potato cells, cell walls and starch}

Mature potato tuber cells mainly consist of starch granules, which generally account for more than a $60 \%$ of their dry weight, and dietary fiber (cell walls) (Ek, Wang, Copeland, \& Brand-Miller, 2014; Wills, Lim, \& Greenfield, 1984). These cell walls comprise a network of cellulose, cross-linking glycans, and pectins (Frost et al., 2016). Figure 1 shows CLSM images of the intact cells and individual cell components isolated from potato tubers (without any autofluorescence from native polyphenols) and used in subsequent sections, together with their FT-IR spectra.

As observed in the micrographs (Figure 1a), the methodology employed for the isolation of intact cells and cell components achieved effective separation of the different constituents. Their FT-IR spectra exhibited characteristic bands of polysaccharides. Specifically, the spectrum of the cell walls showed characteristic bands of pectins and cellulose, such as those ascribed to the esterified $\left(1732 \mathrm{~cm}^{-1}\right)$ and nonesterified carboxyl groups $\left(1603 \mathrm{~cm}^{-1}\right)$ of pectins, methyl esters of pectins $\left(1416 \mathrm{~cm}^{-1}\right)$, $\mathrm{CH}_{2}$ groups in cellulose $\left(1317 \mathrm{~cm}^{-1}\right)$ or ring stretching indicative of $\beta$-glycosidic linkages in cellulose $\left(893 \mathrm{~cm}^{-1}\right)$ (Szymanska-Chargot, Chylinska, Kruk, \& Zdunek, 2015). On the other hand, starch (Figure $1 \mathrm{~b}$ ) exhibited its characteristic $\mathrm{C}-\mathrm{O}$ and $\mathrm{C}-\mathrm{C}$ stretching vibrations modes in the range $1200-1000 \mathrm{~cm}^{-1}$, showing bands centered at 991, 1075, and $1148 \mathrm{~cm}^{-1}$ (Rashid, Omari, Leharne, Chowdhry, \& Badwan, 2012). The intact cells showed the contribution of both cell walls and starch in their spectra (Figure 1b). 
The results from the total starch content assay indicated that the cells isolated from the potato tubers used in this work had a starch content of $74 \pm 2 \%$ of their dry weight. This value is in agreement with starch contents previously reported for Sebago potato tubers, which vary in the range of $57.2-74.7 \%$ depending on the collection period (Wills et al., 1984).

\subsection{Binding capacity}

Figure 2 shows the binding isotherms for the different phenolic compounds and potato cell components studied in this work. The statistical analysis of the data is summarized in Figure 3. The amount of absorbed phenolics after 2 hours of incubation generally increased with their concentration in solution, and was both polyphenol- and substratedependent.

INSERT FIGURE 2 ABOUT HERE

INSERT FIGURE 3 ABOUT HERE

In general, (+)-catechin exhibited the highest binding for all substrates (up to $\sim 50$ $\mu \mathrm{mol} / \mathrm{g}$ ) amongst the studied phenolic compounds, although binding capacity to the cell walls was similar for phloridzin. On the other hand, the binding capacity of vanillic acid was found to be consistently low. Various studies have reported increased binding affinity of phenolic compounds for polysaccharides with increasing molecular weight 
(Bindon et al., 2010; Le Bourvellec et al., 2005; Le Bourvellec et al., 2004; Le Bourvellec \& Renard, 2005; Renard et al., 2001). Although these studies refer to olimeric phenolic compounds (condensed tannins) and may not be directly comparable with our results, in general, a greater number of hydroxyl groups in larger molecules would imply additional potential interaction sites (Jakobek, 2015). Vanillic acid is both a smaller molecule and has only a single hydroxyl group per molecule and, thus, its lower binding capacity was not surprising. However, having more hydroxyl groups in its structure, phloridzin did not exhibit the greatest binding affinities for potato cells or isolated starch, only showing comparable capacity to that of $(+)$-catechin with isolated cell walls. Factors such as the stereochemistry of polyphenols have also been suggested to have an effect on their absorption capacity (Le Bourvellec et al., 2004), and the steric hindrance of phloridzin due to its attached glucose molecule might have limited its absorption onto starch granules and the cells, whose specific surface areas readily available for interaction may be smaller than that of the broken cell walls. In a previous work, Le Bourvellec and Renard (2005) showed that the physical state of the cell walls (dried under different conditions and, thus, having different physical characteristics but the same polysaccharide composition) affected their adsorption capacity, due to their different surface area. Liu, Martinez-Sanz, Lopez-Sanchez, Gilbert, and Gidley (2017) also showed that the structural modification induced on cellulose by different processing techniques had an impact on the adsorption of polyphenols. Compared to cell walls, the starch is organized as a compact semi-crystalline structure and has lower swelling ability than cell walls. Thus a lower binding affinity of phloridzin on starch may be expected due to steric hindrance. Differences in polarity amongst the phenolic compounds and the polysaccharides constituting the various cell components may also play a role in the observed differences, as adsorption from solution is actually the result 
of a balance between the affinity of the phenolic compounds for the substrate versus their affinity for the solvent.

In the case of $(+)$-catechin, no significant differences were observed between the amount of polyphenol bound to starch, cell walls and intact cells. Interestingly, $(+)-$ catechin was able to penetrate the cell wall barrier and interact with the starch granules inside the cells. Otherwise, the $74 \%$ of the cells' dry weight which is accounted by starch granules would not participate in the absorption of $(+)$-catechin and the bound amount per weight of dry cells would have been lower. CLSM observations were conducted in order to confirm the presence of $(+)$-catechin inside the potato cells (see Section 3.4, Figure 6).

Interestingly, the amount of $(+)$-catechin bound to broken cells was significantly greater than that bound to individual cell components (i.e. starch and cell walls) or intact cells (Figure 3). A plausible explanation for these results might be related to the physical state of the substrates and the resulting specific surface available for interaction. The intense magnetic agitation treatment carried out to break the cells also damaged the starch granules increasing their surface area for binding as shown in Figure 4. In order to ascertain whether this damage was the cause of the significant increase in the binding extent observed for $(+)$-catechin towards the broken cells, isolated starch granules were also subjected to overnight intense magnetic agitation following the same procedure used to break the cells, before evaluating their binding to (+)-catechin at $2 \mathrm{mM}$ concentration. As shown in Figure 4a (left column) the damaged starch granules in the 'broken cells' samples have distinctive granule morphology compared to intact starch granules (right column). A $40 \%$ increase in the amount of bound (+)-catechin was indeed observed, providing a plausible explanation of the increased binding reported for the broken cells. 


\section{INSERT FIGURE 4 ABOUT HERE}

Regarding phloridzin, a different trend was observed. In this case, the binding affinity of the polyphenol for the cell walls was significantly higher than for starch (cf. Figure 3). As mentioned above, the high number of hydroxyl groups in its structure involves a number of potential interaction sites with the polysaccharides via hydrogen bonds. However, steric hindrance might represent a limitation for its access and, thus, binding to compact structures such as that of starch granules. Han et al. (2015) recently showed that while catechin could successfully diffuse into the pores of starch granules, rutin, which has a similar phenolic structure but is conjugated with a disaccharide, did not diffuse at all (Han et al., 2015). A similar phenomenon might occur in the case of phloridzin, significantly reducing its absorption onto the starch granules. Again, no significant differences were found between the amount of phloridzin bound to intact cells and starch. Being starch the majoritarian component of the cells, these results suggest that phloridzin was also capable of penetrating the cell walls and bind to intracellular starch.

Finally, vanillic acid showed little affinity for potato cells and isolated cell components, presumably because it is a small molecule with only one hydroxyl group per molecule. A higher concentration of the phenolic compound was needed to observe significant solution depletion in the presence of the substrates, and only cell walls and broken cells (the components with higher available surface areas) showed convincing evidence for binding through a reduction in vanillic acid concentration in the solution. Unlike $(+)$ catechin and phloridzin, vanillic acid is negatively charged in neutral solution, which 
might also have impacted its binding to the potato cells and cell components due to electrostatic repulsions. However, the effect of this negative charge was found to be negligible as binding was similar at $\mathrm{pH}$ values where the negative charge was neutralised (see Section 3.6).

It is worth mentioning that the data obtained for binding of phenolic compounds to polysaccharides at different concentrations and at equilibrium can be generally fitted to type I (Langmuir) isotherms (Le Bourvellec et al., 2005; Le Bourvellec et al., 2004; Phan et al., 2015). However, in the binding isotherms presented in this work, a plateau value was not reached for some of the systems (cf. Figure 2), due to the impossibility of increasing the polyphenol concentration because of solubility limitations.

\subsection{Binding kinetics}

Figure 5 shows the binding kinetic profiles of $(+)$-catechin and phloridzin $(2 \mathrm{mM})$ to the different plant-based substrates assayed in this work. Vanillic acid was excluded from this assay due to its low binding capacities. All the curves show an initial increase in the amount of bound polyphenol with time until a plateau was reached. In all cases, a $2 \mathrm{~h}$ incubation period was enough to reach the plateau.

\section{INSERT FIGURE 5 ABOUT HERE}

The polyphenols bound the different cell components at different rates in the first $2 \mathrm{~h}$ of incubation. For (+)-catechin, binding to starch was found to be the fastest to reach the plateau (after only $20 \mathrm{~min}$ ), while the cell walls absorbed polyphenol molecules in a 
slower manner. Again, the observed differences can be attributed to the structure and physical organisation of the polysaccharide-based substrates. Starch is organised in the form of compact granules, whose available surface will be only marginally altered upon hydration in the polyphenol solution. In contrast, cell walls are organised in the form of interpenetrating hydrogels with great water uptake capacity, whose fibrillar structure swells in aqueous solution. As the fibre swell, more binding sites become available and the polyphenol diffuses inside its porous structure, and thus the binding progresses over time, eventually surpassing the binding capacity of starch after $\approx 1 \mathrm{~h}$ incubation. These results are in agreement with previous reports which suggested that the conformational organisation of polysaccharides play an important role on their binding to polyphenols (Le Bourvellec et al., 2005). Regarding the broken cells, a very fast binding was observed in the first 10 minutes, since most of the available binding sites were readily available for interaction due to the disruption of the cell walls and the hydrated state of these samples.

In the case of phloridzin, again, a different trend was observed. Not only did it bind to cell walls to a greater extent than to starch, but it also bound them at a higher rate. Thus, both the binding capacity and affinity of phloridzin were higher for cell walls than for starch. These results agree with the previous suggestion that the steric hindrance of this larger molecule might represent a limitation for its binding to compact structures, while its affinity for swollen polysaccharides is higher.

The slowest binding profiles in both cases were observed for the binding of the polyphenols with the intact cells. As the polyphenols would have to penetrate the cell wall barrier to interact with the starch granules, a slow solution depletion could be expected, as the binding rate in this case would be limited by the diffusion of the polyphenols through the intact cell walls. This slow binding rate together with the 
binding extent to intact cells being comparable to that of starch are indicative of the ability of the polyphenols to penetrate into the potato cells.

In all cases, the binding of polyphenols to potato cells and cell components took place within the first $2 \mathrm{~h}$ of incubation, indicating that the duration of a typical human digestion process would be enough for these interactions to take place upon simultaneous consumption of polyphenol ingredients and plant-based foods (refer to Section 3.6. for results at gastric $\mathrm{pH}$ ), not to mention the long-term storage of polyphenol-rich vegetable and other products.

\subsection{Location of bound polyphenols within the cells and cell components}

Figure 6 shows representative images of starch, cell walls, intact cells and broken cells after $2 \mathrm{~h}$ incubation in the presence of $2 \mathrm{mM}$ solutions of $(+)$-catechin, and respective controls in the absence of phenolic compounds. The intrinsic fluorescence of $(+)$ catechin allowed confirmation of its location of binding within the cells and cell components. However, no significant autofluorescence (as compared with the background signal) could be detected for phloridzin or vanillic acid, so the comparison could not be made (results not shown).

\section{INSERT FIGURE 6 ABOUT HERE}

Although the fluorescence of the cell walls in the presence of $(+)$-catechin was not so marked, presumably due to their high swelling degree and thus low density, the binding of this polyphenol to the starch granules was evidenced by the intense and localized 
fluorescence shown in Figure 6a. Moreover, not only did (+)-catechin bind to the isolated starch granules, but it could also bind to them inside the intact cells, which confirmed the capability of polyphenols, specifically $(+)$-catechin, to cross the cell walls as hypothesized in Section 3.2.

These interesting results suggest, for the first time, the potential of plant cells and, in particular, potato cells as delivery vehicles for bioactive ingredients, specifically polyphenols. As cell walls (dietary fiber) are not digestible, the contents of the intact cells are expected to be delivered to the large intestine where the fermentation by bacteria would allow their release, provided the cells remain intact upon passage through the gastrointestinal tract (Dhital et al., 2016). Intracellular starch is probably acting as a sink, with binding of $(+)$-catechin promoting uptake of additional $(+)$ catechin across the cell wall.

\subsection{Effect of $\mathrm{pH}$ on the binding extent}

In order to assess the effect of the $\mathrm{pH}$ on the binding of the phenolic compounds to the different substrates, binding assays were also conducted at $\mathrm{pH}=3$, for a fixed phenolic compound concentration $(2 \mathrm{mM})$ and incubation period $(2 \mathrm{~h})$. This $\mathrm{pH}$ was selected because it is close to the human gastric pH (Minekus et al., 2014), and it is below the $\mathrm{pK}_{\mathrm{a}}$ of ca 4.5 for vanillic acid (Beltrán et al., 2003), so its dissociation and thus negative charge could be repressed. Results are shown in Figure 7 , together with the data obtained at neutral $\mathrm{pH}$ for comparison purposes.

INSERT FIGURE 7 ABOUT HERE 
The binding extent for the three phenolic compounds was similar at both $\mathrm{pH}$ values. No significant differences were observed except for the binding of $(+)$-catechin and phloridzin to cell walls, which was significantly lower at $\mathrm{pH} 3$.

The fact that the binding of vanillic acid to potato cells and cell components did not increase at $\mathrm{pH} 3$ compared to neutral $\mathrm{pH}$ suggests that the potential electrostatic repulsion between the negatively charged phenolic acid (present at $\mathrm{pH} 7$ but essentially not at $\mathrm{pH} 3$ ) and the polysaccharides did not significantly affect the affinity of vanillic acid for the assayed substrates. These results are in agreement with previous work which concluded that the native charge of polyphenols is only a secondary factor in the interactions between polyphenols and neutral polysaccharides such as cellulose (Phan et al., 2015). Regarding the presence of negatively charged polysaccharides (i.e. pectins) in the potato cell walls, our results are also in agreement with Padayachee et al. (2012) who reported similar binding affinities for phenolic acids towards cellulose and cellulose-pectin composites at equilibrium, despite the negative charge of the latter, further suggesting that the impact of electrostatic repulsions was a minor factor (Padayachee et al., 2012b). These findings support the hypothesis that the binding of the phenolic compounds to the polysaccharides in potato cells is mainly mediated by hydrogen bonds and hydrophobic interactions with the aromatic ring.

\subsection{Effect of cooking on binding}

Plant-derived ingredients, especially potatoes, are usually cooked before consumption, which generally involves subjecting them to thermal treatments. The hydrothermal processing of plant cells has a substantial impact on their structure, with major changes caused by the gelatinization of the starch granules (Wang \& Copeland, 2013). In order to assess the effect of cooking on the affinity of potato cells for the phenolic 
compounds, these were incubated in the presence of 'cooked cells', i.e. cells isolated from boiled potato tubers, and the amount of bound phenolic compounds from $2 \mathrm{mM}$ solutions was determined after $2 \mathrm{~h}$. As starch becomes soluble in aqueous solution after gelatinization, and therefore it cannot be separated from the binding media by centrifugation, the assay was only carried out for the intact cells in this case. Results are shown in Figure 8a, together with those obtained for the raw cells from Section 3.2.

\section{INSERT FIGURE 8 ABOUT HERE}

The amount of all the phenolic compounds bound to the potato cells significantly increased when the latter had been previously cooked. As observed in Figure 8b, the integrity of the starch granules within the cells was lost, and a swollen mass of gelatinized starch filled the cooked cells. Rather than being organized in the form of compact, semi-crystalline granules as in the raw cells, the starch in the cooked cells exhibited an amorphous swollen structure which would considerably increase the accessibility of its potential binding sites, consistent with the observed increase in the binding capacity of the boiled cells. Again, these results suggest that the conformational organization of the polysaccharides within plant cells plays a key role in their binding to phenolic compounds.

Finally, the potential of potato cells as delivery vehicles for the encapsulation of phenolic compounds seemed to be enhanced upon cooking, as their loading capacity significantly increased. The ability of the cooked cells to accumulate phenolic compounds was further confirmed by the localised fluorescence of $(+)$-catechin confined within the limits of their cell walls in Figure $8 \mathrm{~b}$. 
Overall, the present work provides new information about the binding of phenolic compounds to potato cells and cell components, as a model polysaccharide-based food system. The obtained results suggest, for the first time, the potential of potato cells as encapsulation vehicles for phenolic compounds. Future, complementary studies should explore the reversibility of these polyphenol-polysaccharide binding and its effect on the release of the phenolic compounds throughout the gastrointestinal tract, with an emphasis on the impact of gelatinization of starch on the performance of potato cells as potential delivery vehicles for these bioactive compounds.

\section{Conclusions}

The binding of three phenolic compounds (vanillic acid, phloridzin and (+)-catechin) to potato cells and individual cell components, i.e. cell walls and starch granules, was studied in this work. The cells and cell components were successfully isolated from potato tubers and mainly consisted of polysaccharides, as inferred from their FT-IR spectra. Significant amounts of phenolic compounds (up to $\sim 50 \mu \mathrm{mol} / \mathrm{g}$ ) bound to the different substrates. In general, the extent of binding to the different substrates followed the order $(+)$-catechin $>$ phloridzin $>$ vanillic acid, which could be mainly attributed to the amount of potential binding sites (hydroxyl groups) in their structure as well as the greater steric hindrance of phloridzin. The electrostatic interactions did not significantly impact the binding capacities, which were similar at $\mathrm{pH} 3.0$ and 7.4. The physical organization of the polysaccharides in each cell component was found to affect both the binding extent of the phenolic compounds and their binding rate. Phloridzin, possibly due to its large steric volume, exhibited a similar binding capacity as (+)-catechin only towards the isolated cell walls, whose swollen structure facilitated the exposure of their 
binding sites, while its binding capacity towards the starch granules (compact structures) and the intact cells (consisting mainly of starch granules) was significantly lower. After $2 \mathrm{~h}$ of incubation, the binding profiles approached a plateau, suggesting that the duration of a digestion process upon simultaneous consumption of phenolic compounds and plant-based food products would be enough for these interactions to take place. Of particular interest, the phenolic compounds (especially (+)-catechin) were able to penetrate the intact cells and bind to the starch granules within them. Consequently, the potential of intact potato cells to be exploited as natural delivery vehicles for the encapsulation of polyphenols is suggested, which could have industrial applications besides nutritional implications. This potential could be enhanced by previously cooking (boiling) the potato cells, as their loading capacity dramatically increased due to the gelatinization of the starch and consequent increased accessibility of its binding sites. If these cellular capsules survive the stomach and small intestine, they would also deliver significant payloads of resistant starch to the microbiota in the large intestine.

\section{Acknowledgements}

Laura G. Gómez-Mascaraque is recipient of a predoctoral contract from the Spanish Ministry of Economy, Industry and Competitiveness (MINECO), Call 2013. The authors would like to thank the Spanish MINECO project AGL2015-63855-C2-1-R and the Australian Research Council Centre of Excellence in Plant Cell Walls (CE110001007) for financial support and Meena Shrestha for her help with the total starch analysis assay. 


\section{References}

Aguilera, J. M., Cadoche, L., López, C., \& Gutierrez, G. (2001). Microstructural changes of potato cells and starch granules heated in oil. Food Research International, 34(10), 939-947.

Aleixandre, A., \& Miguel, M. (2016). Dietary fiber and blood pressure control. Food \& Function, 7(4), 1864-1871.

Bautista-Ortín, A. B., Cano-Lechuga, M., Ruiz-García, Y., \& Gómez-Plaza, E. (2014). Interactions between grape skin cell wall material and commercial enological tannins. Practical implications. Food Chemistry, 152, 558-565.

Beltrán, J. L., Sanli, N., Fonrodona, G., Barrón, D., Özkan, G., \& Barbosa, J. (2003). Spectrophotometric, potentiometric and chromatographic pKa values of polyphenolic acids in water and acetonitrile-water media. Analytica Chimica Acta, 484(2), 253-264.

Bindon, K. A., Smith, P. A., \& Kennedy, J. A. (2010). Interaction between grape-derived proanthocyanidins and cell wall material. 1. Effect on proanthocyanidin composition and molecular mass. Journal of Agricultural and Food Chemistry, 58(4), 2520-2528.

Conlon, M. A., \& Topping, D. L. (2016). Dietary polysaccharides and polyphenols can promote health by influencing gut microbiota populations. Food \& Function, 7(4), 1730-1730.

Dhital, S., Bhattarai, R. R., Gorham, J., \& Gidley, M. J. (2016). Intactness of cell wall structure controls the in vitro digestion of starch in legumes. Food \& function, 7(3), 1367-1379.

Ek, K. L., Wang, S., Copeland, L., \& Brand-Miller, J. C. (2014). Discovery of a low-glycaemic index potato and relationship with starch digestion in vitro. British Journal of Nutrition, 111(04), 699-705.

Frost, J. K. T., Flanagan, B. M., Brummell, D. A., O'Donoghue, E. M., Mishra, S., Gidley, M. J., \& Monro, J. A. (2016). Composition and structure of tuber cell walls affect in vitro digestibility of potato (Solanum tuberosum L.). Food \& Function, 7(10), 4202-4212.

Gómez-Mascaraque, L. G., Lagarón, J. M., \& López-Rubio, A. (2015). Electrosprayed gelatin submicroparticles as edible carriers for the encapsulation of polyphenols of interest in functional foods. Food Hydrocolloids, 49, 42-52.

Han, J., Britten, M., St-Gelais, D., Champagne, C. P., Fustier, P., Salmieri, S., \& Lacroix, M. (2011). Polyphenolic compounds as functional ingredients in cheese. Food Chemistry, 124(4), 1589-1594.

Han, S., Choi, S.-H., Kim, W., Kim, B.-Y., \& Baik, M.-Y. (2015). Infusion of catechin into native corn starch granules for drug and nutrient delivery systems. Food Science and Biotechnology, 24(6), 2035-2040.

Jakobek, L. (2015). Interactions of polyphenols with carbohydrates, lipids and proteins. Food chemistry, 175, 556-567.

Kaulmann, A., \& Bohn, T. (2016). Bioactivity of Polyphenols: Preventive and Adjuvant Strategies toward Reducing Inflammatory Bowel Diseases-Promises, Perspectives, and Pitfalls. Oxidative Medicine and Cellular Longevity, 2016.

Klinder, A., Shen, Q., Heppel, S., Lovegrove, J. A., Rowland, I., \& Tuohy, K. M. (2016). Impact of increasing fruit and vegetables and flavonoid intake on the human gut microbiota. Food \& Function, 7(4), 1788-1796.

Kugimiya, M. (1990). Separation of cotyledon cells of legumes by successive treatments with acid and alkali. Nippon Shokuhin Kogyo Gakkaishi, 37(11), 867-871.

Kumpoun, W., Motomura, Y., \& Nishizawa, T. (2015) Free and bound polyphenols in mango fruit peel as functional food ingredients with high antioxidant activity. Vol. 1088. Acta Horticulturae (pp. 515-520).

Le Bourvellec, C., Bouchet, B., \& Renard, C. (2005). Non-covalent interaction between procyanidins and apple cell wall material. Part III: Study on model polysaccharides. Biochimica et Biophysica Acta (BBA)-General Subjects, 1725(1), 10-18. 
Le Bourvellec, C., Guyot, S., \& Renard, C. (2004). Non-covalent interaction between procyanidins and apple cell wall material: Part I. Effect of some environmental parameters. Biochimica et Biophysica Acta (BBA)-General Subjects, 1672(3), 192-202.

Le Bourvellec, C., Guyot, S., \& Renard, C. (2009). Interactions between apple (Malus x domestica Borkh.) polyphenols and cell walls modulate the extractability of polysaccharides. Carbohydrate Polymers, 75(2), 251-261.

Le Bourvellec, C., \& Renard, C. (2005). Non-covalent interaction between procyanidins and apple cell wall material. Part II: Quantification and impact of cell wall drying. Biochimica et Biophysica Acta (BBA)-General Subjects, 1725(1), 1-9.

Le Bourvellec, C., \& Renard, C. M. G. C. (2012). Interactions between Polyphenols and Macromolecules: Quantification Methods and Mechanisms. Critical Reviews in Food Science and Nutrition, 52(3), 213-248.

Liu, C., Ge, S., Yang, J., Xu, Y., Zhao, M., Xiong, L., \& Sun, Q. (2016). Adsorption mechanism of polyphenols onto starch nanoparticles and enhanced antioxidant activity under adverse conditions. Journal of Functional Foods, 26, 632-644.

Liu, D., Martinez-Sanz, M., Lopez-Sanchez, P., Gilbert, E. P., \& Gidley, M. J. (2017). Adsorption behaviour of polyphenols on cellulose is affected by processing history. Food Hydrocolloids, 63, 496-507.

Minekus, M., Alminger, M., Alvito, P., Ballance, S., Bohn, T., Bourlieu, C., ... Dupont, D. (2014). A standardised static in vitro digestion method suitable for food-an international consensus. Food \& Function, 5(6), 1113-1124.

Moreno-Indias, I., Sanchez-Alcoholado, L., Perez-Martinez, P., Andres-Lacueva, C., Cardona, F., Tinahones, F., \& Queipo-Ortuno, M. I. (2016). Red wine polyphenols modulate fecal microbiota and reduce markers of the metabolic syndrome in obese patients. Food \& Function, 7(4), 1775-1787.

Padayachee, A., Netzel, G., Netzel, M., Day, L., Zabaras, D., Mikkelsen, D., \& Gidley, M. (2012a). Binding of polyphenols to plant cell wall analogues-Part 1: Anthocyanins. Food Chemistry, 134(1), 155-161.

Padayachee, A., Netzel, G., Netzel, M., Day, L., Zabaras, D., Mikkelsen, D., \& Gidley, M. (2012b). Binding of polyphenols to plant cell wall analogues-Part 2: Phenolic acids. Food chemistry, 135(4), 2287-2292.

Peyron, M.-A., Mishellany, A., \& Woda, A. (2004). Particle size distribution of food boluses after mastication of six natural foods. Journal of Dental Research, 83(7), 578-582.

Phan, A. D. T., Netzel, G., Wang, D., Flanagan, B. M., D’Arcy, B. R., \& Gidley, M. J. (2015). Binding of dietary polyphenols to cellulose: Structural and nutritional aspects. Food Chemistry, 171, 388-396.

Rashid, I., Omari, M. H. A., Leharne, S. A., Chowdhry, B. Z., \& Badwan, A. (2012). Starch gelatinization using sodium silicate: FTIR, DSC, XRPD, and NMR studies. Starch-Stärke, 64(9), 713-728.

Renard, C. M., Baron, A., Guyot, S., \& Drilleau, J.-F. (2001). Interactions between apple cell walls and native apple polyphenols: quantification and some consequences. International Journal of Biological Macromolecules, 29(2), 115-125.

Rustioni, L., Fiori, S., \& Failla, O. (2014). Evaluation of tannins interactions in grape (Vitis vinifera L.) skins. Food Chemistry, 159, 323-327.

Shi, J., Nawaz, H., Pohorly, J., Mittal, G., Kakuda, Y., \& Jiang, Y. (2005). Extraction of polyphenolics from plant material for functional foods - Engineering and technology. Food Reviews International, 21(1), 139-166.

Sun-Waterhouse, D., Chen, J., Chuah, C., Wibisono, R., Melton, L. D., Laing, W., .. . Skinner, M. A. (2009). Kiwifruit-based polyphenols and related antioxidants for functional foods: Kiwifruit extract-enhanced gluten-free bread. International Journal of Food Sciences and Nutrition, 60(SUPPL. 7), 251-264. 
Szymanska-Chargot, M., Chylinska, M., Kruk, B., \& Zdunek, A. (2015). Combining FT-IR spectroscopy and multivariate analysis for qualitative and quantitative analysis of the cell wall composition changes during apples development. Carbohydrate Polymers, 115, 93-103.

Wang, S., \& Copeland, L. (2013). Molecular disassembly of starch granules during gelatinization and its effect on starch digestibility: a review. Food \& Function, 4(11), 1564-1580.

Wills, R. B. H., Lim, J. S. K., \& Greenfield, H. (1984). Variation in nutrient composition of Australian retail potatoes over a 12-month period. Journal of the Science of Food and Agriculture, 35(9), 1012-1017.

Zhu, F. (2015). Interactions between starch and phenolic compound. Trends in Food Science \& Technology, 43(2), 129-143. 

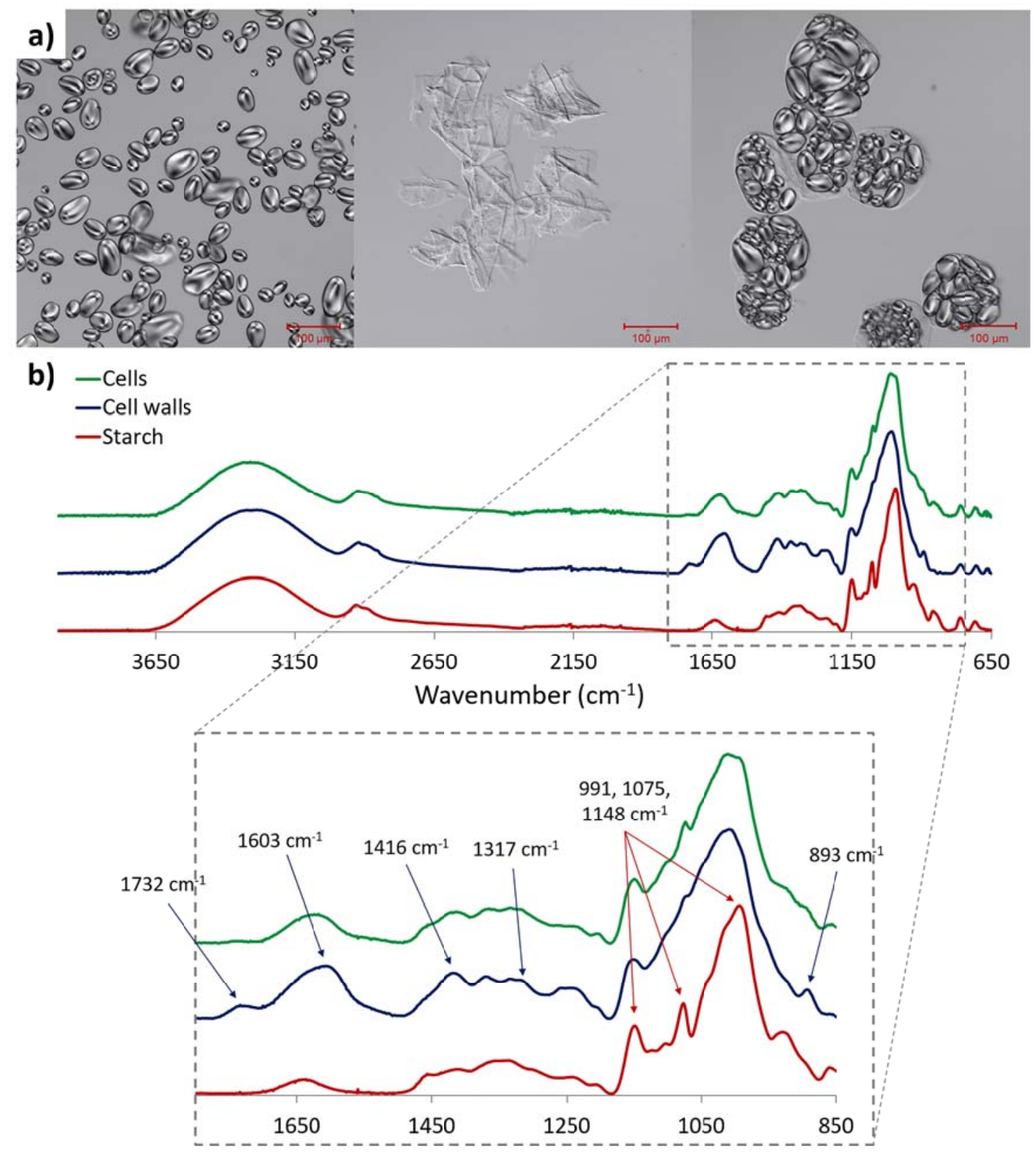

Figure 1. a) CLSM images from suspensions of isolated potato cells and cell components (from left to right: starch, cell walls and intact cells). All scale bars correspond to $100 \mu \mathrm{m}$. b) FT-IR spectra of dried cells and cell components (from top to bottom: intact cells, cell walls and starch). 

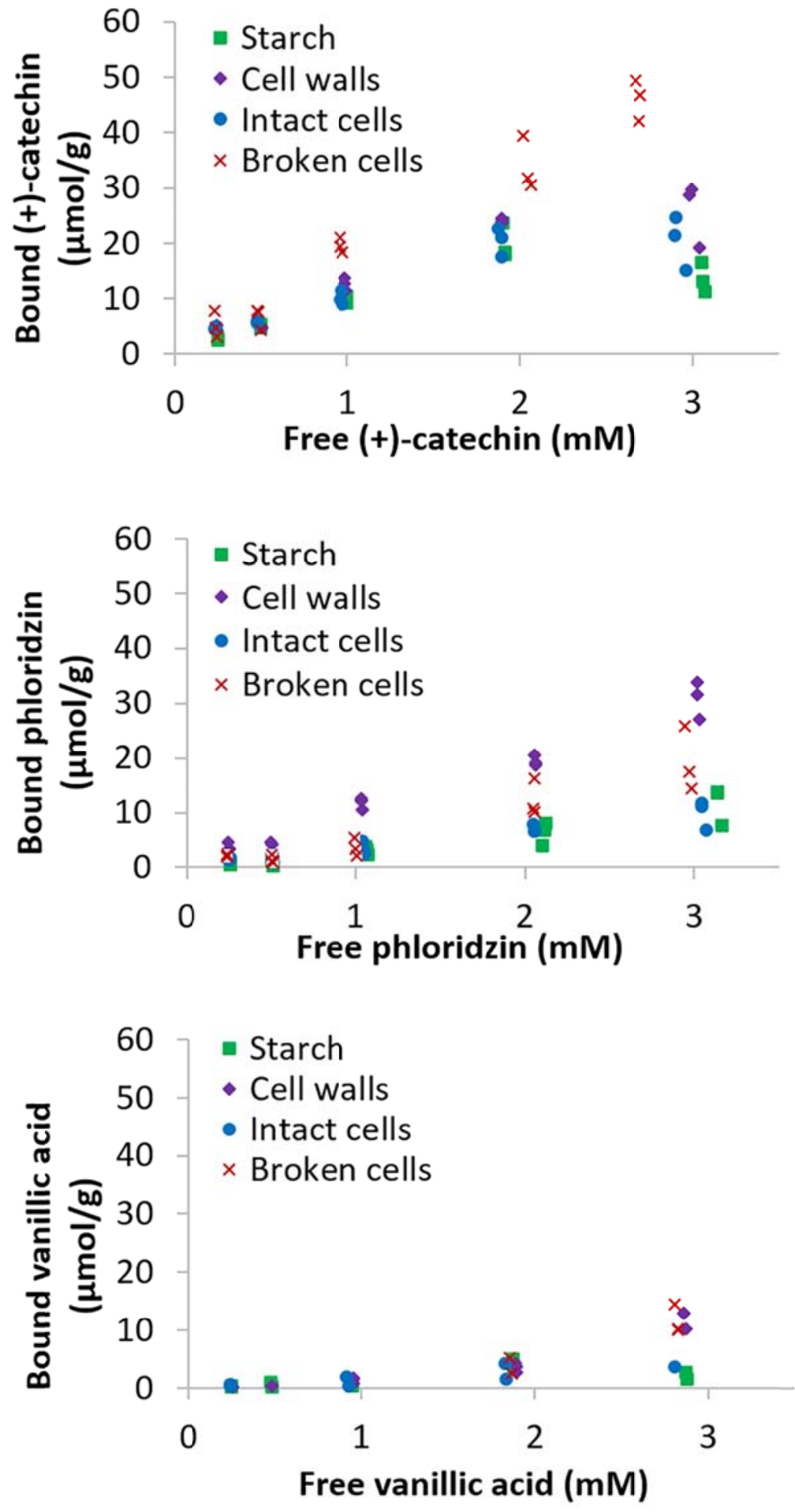

Figure 2. Binding isotherms for the different phenolic compounds - potato cells systems. 

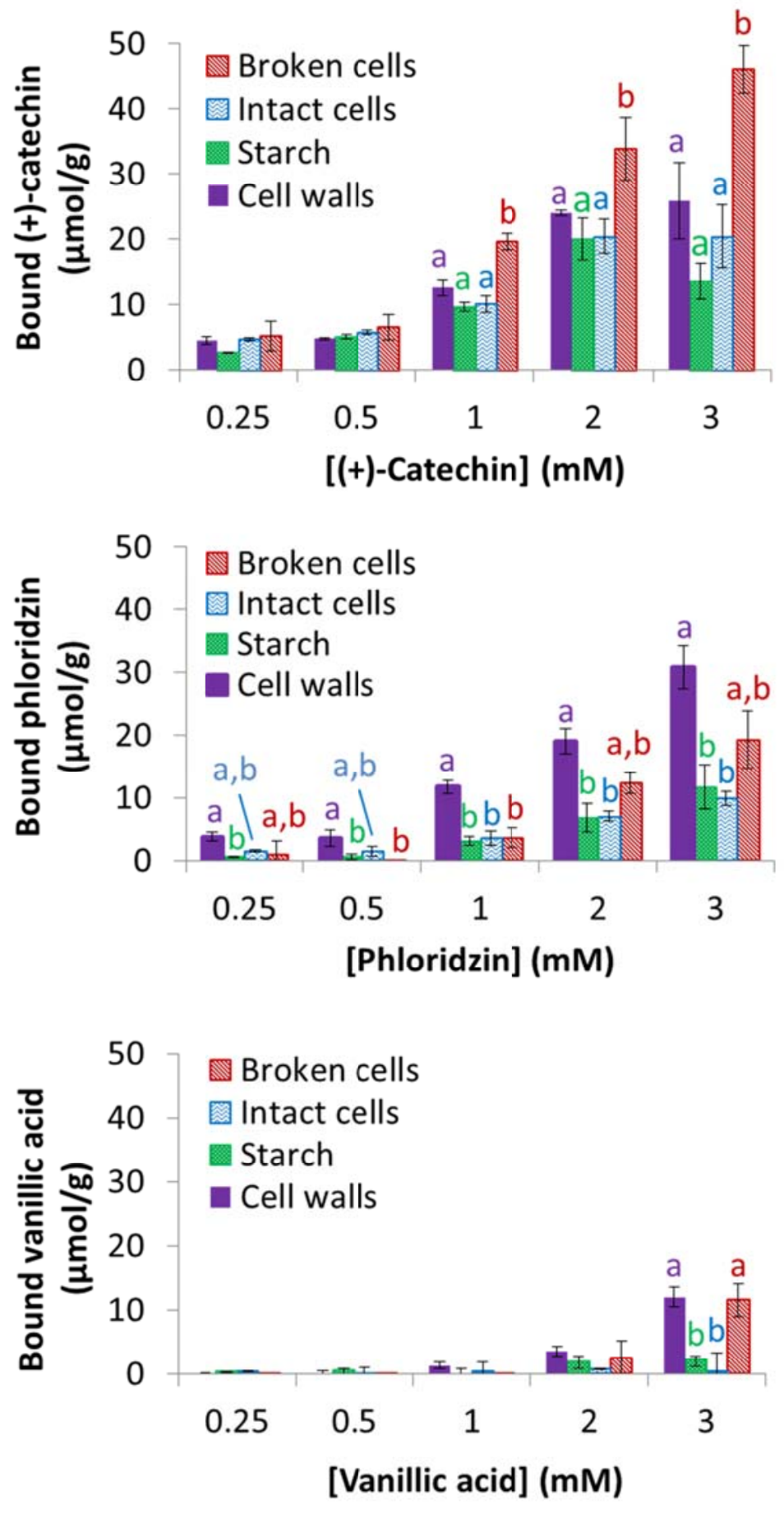

Figure 3. Comparison between the binding capacity of polyphenols to potato cells and cell components at different concentrations after $2 \mathrm{~h}$ incubation. Experiments were performed at least in triplicate. Error bars represent standard deviations. Different letters 
$(\mathrm{a}-\mathrm{c})$ within the same series indicate significant differences at $\mathrm{p}<0.05$ among the samples. No letters indicate no significant differences within the series.
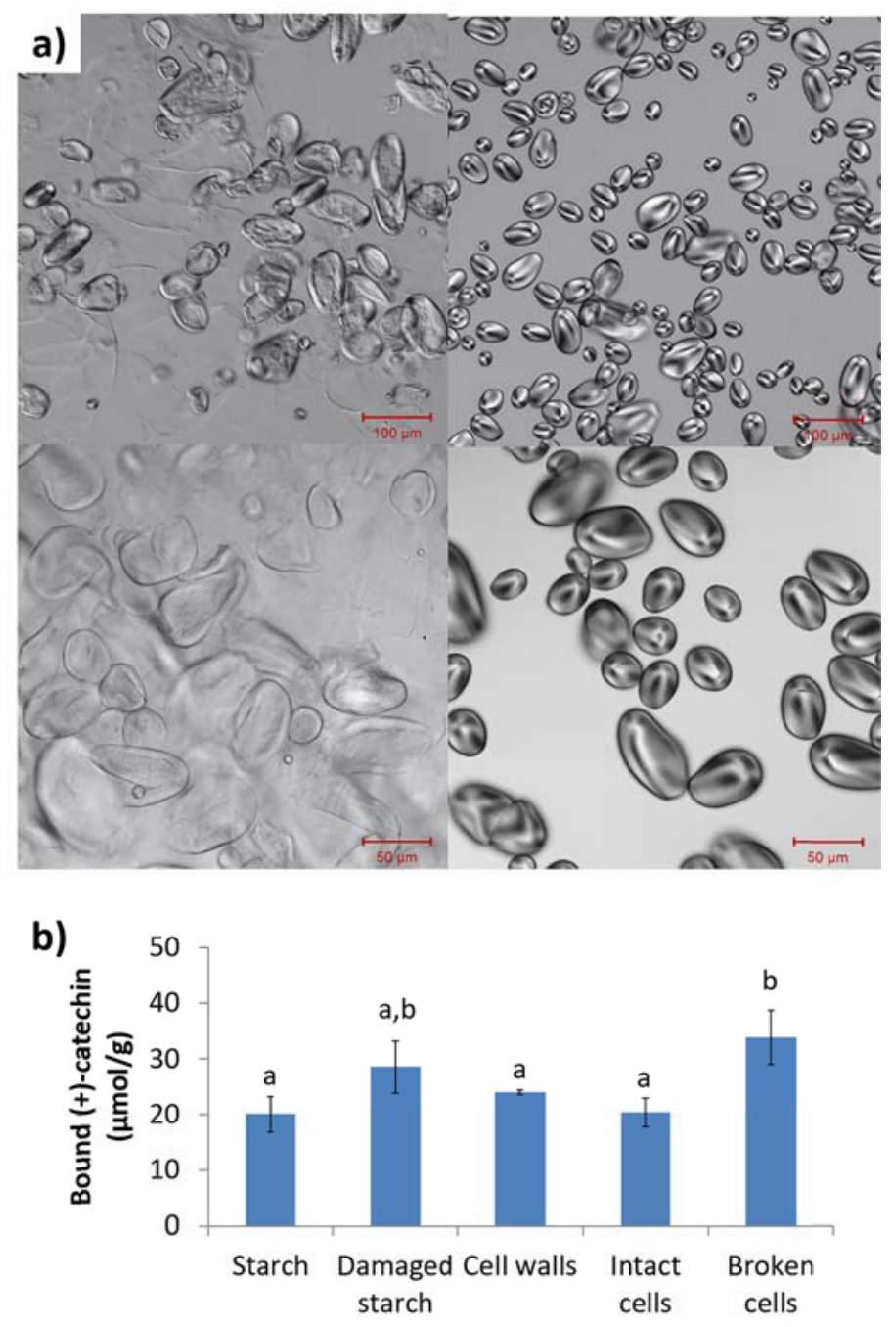

Figure 4. a) CLSM images of broken cells (left) in comparison with intact starch (right) at two different magnifications. Scale bars correspond to $100 \mu \mathrm{m}$ in upper images and $50 \mu \mathrm{m}$ in lower images. b) Binding extent of $2 \mathrm{mM}(+)$-catechin to potato cells and cell components including 'damaged starch' after $2 \mathrm{~h}$ incubation. Experiments were performed at least in triplicate. Error bars represent standard deviations. Different letters $(\mathrm{a}-\mathrm{b})$ indicate significant differences at $\mathrm{p}<0.05$ among the samples. 

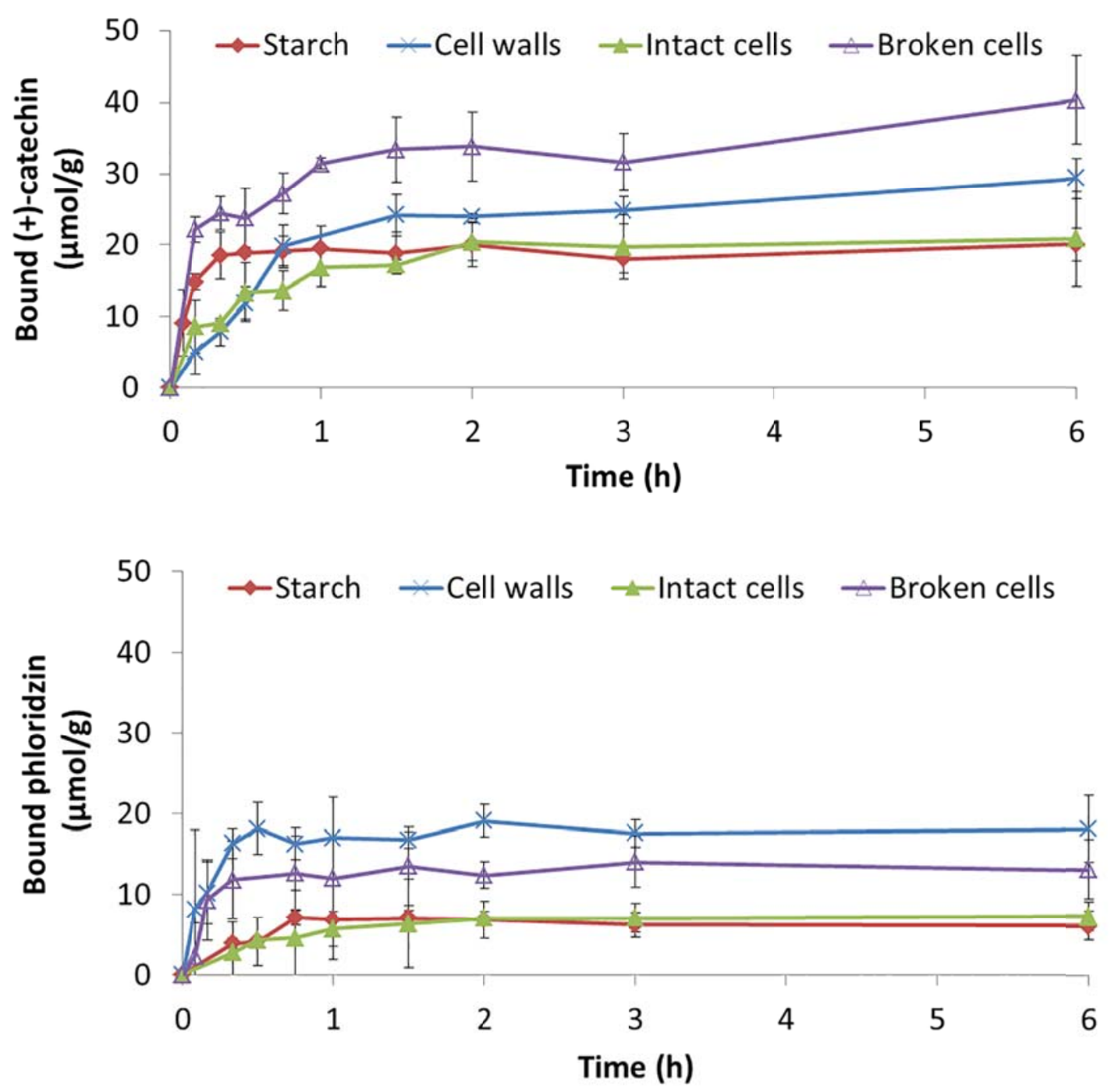

Figure 5. Binding of $(+)$-catechin and phloridzin $(2 \mathrm{mM})$ to potato cells and cell components after different incubation times. Experiments were performed at least in triplicate. Error bars represent standard deviations. 

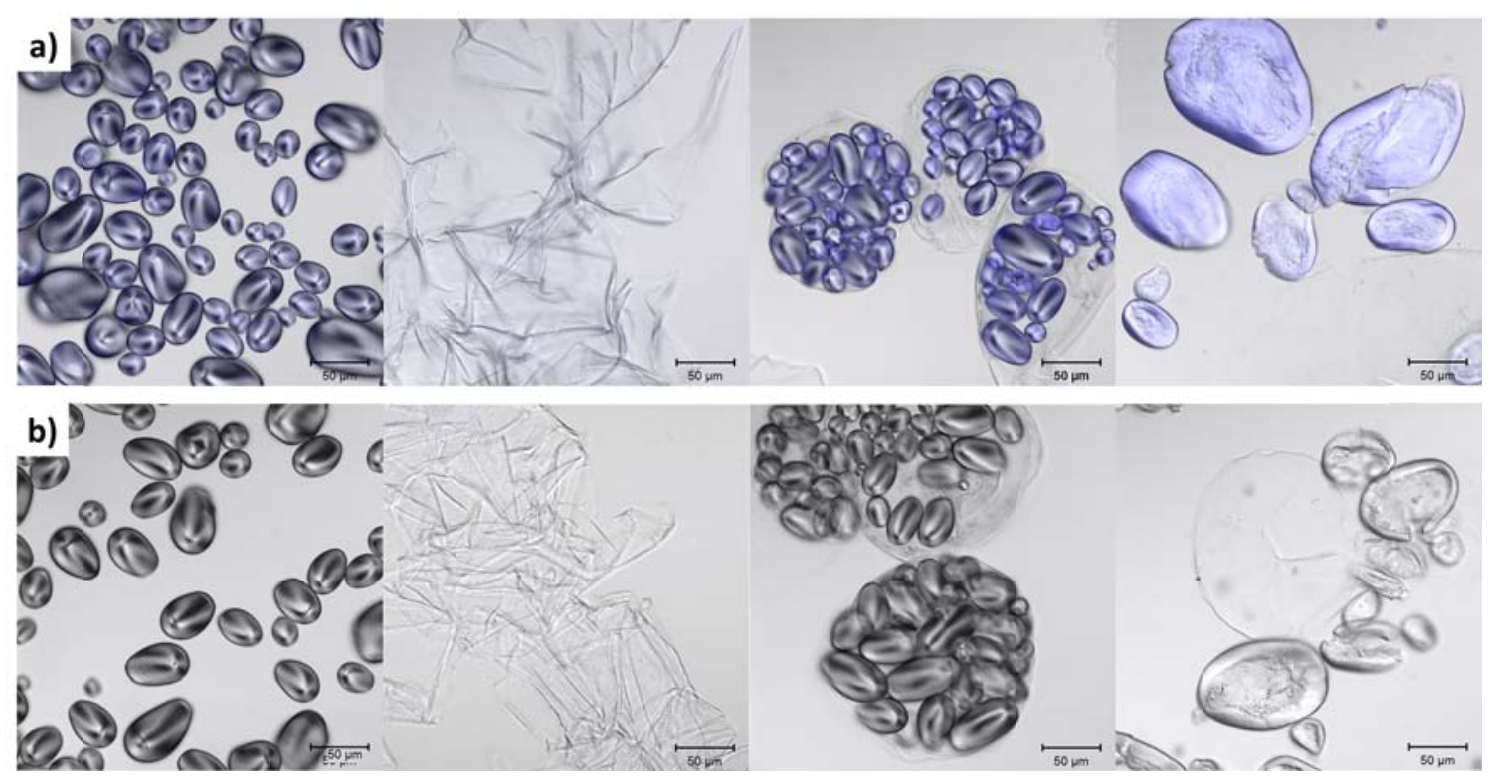

Figure 6. CLSM images of potato cells and cell components (starch, cell walls, intact cells and broken cells, from left to right) after $2 \mathrm{~h}$ contact with $(+)$-catechin (a) and controls in the absence of phenolic compound (b). All scale bars correspond to $50 \mu \mathrm{m}$. The reader is referred to the web version of the article for colour images. 


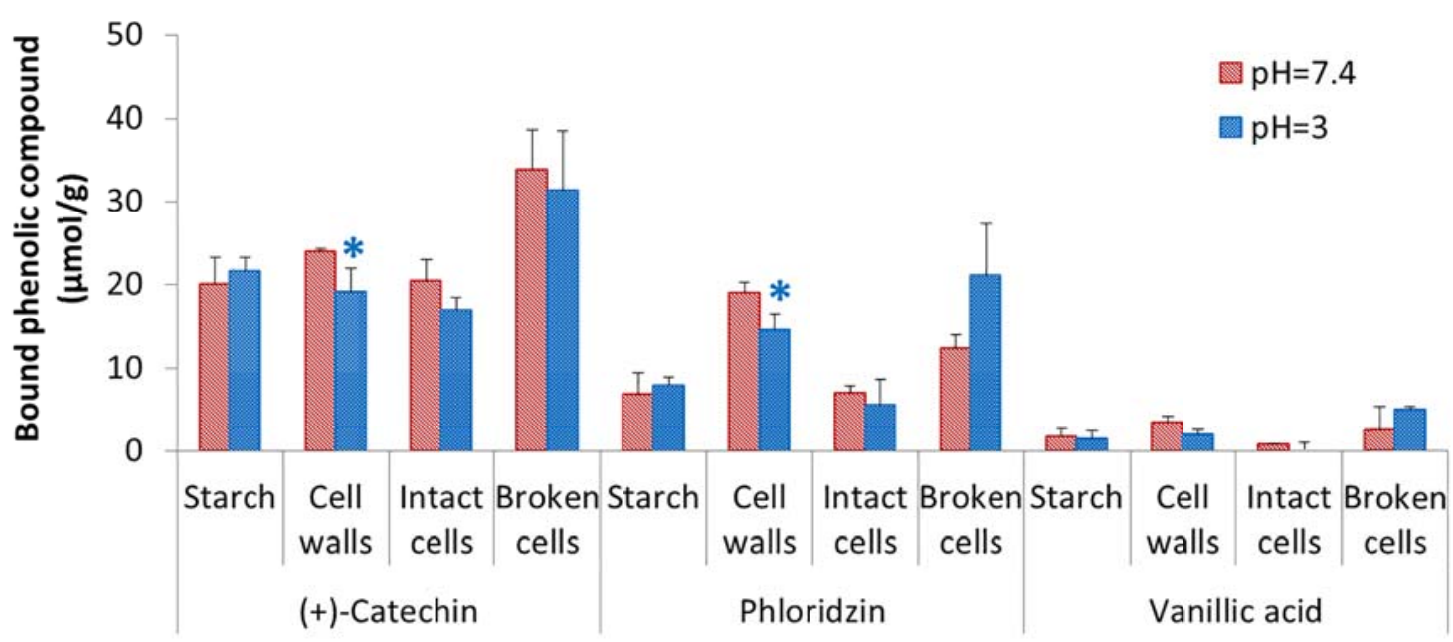

Figure 7. Binding capacity of the phenolic compounds $(2 \mathrm{mM})$ to potato cells and cell components at $\mathrm{pH} 3.0$ and 7.4 after $2 \mathrm{~h}$ incubation. Experiments were performed at least in triplicate. Error bars represent standard deviations. Asterisks $(*)$ indicate significant differences between the results at different $\mathrm{pH}$ values for a given phenolic compound and substrate. 

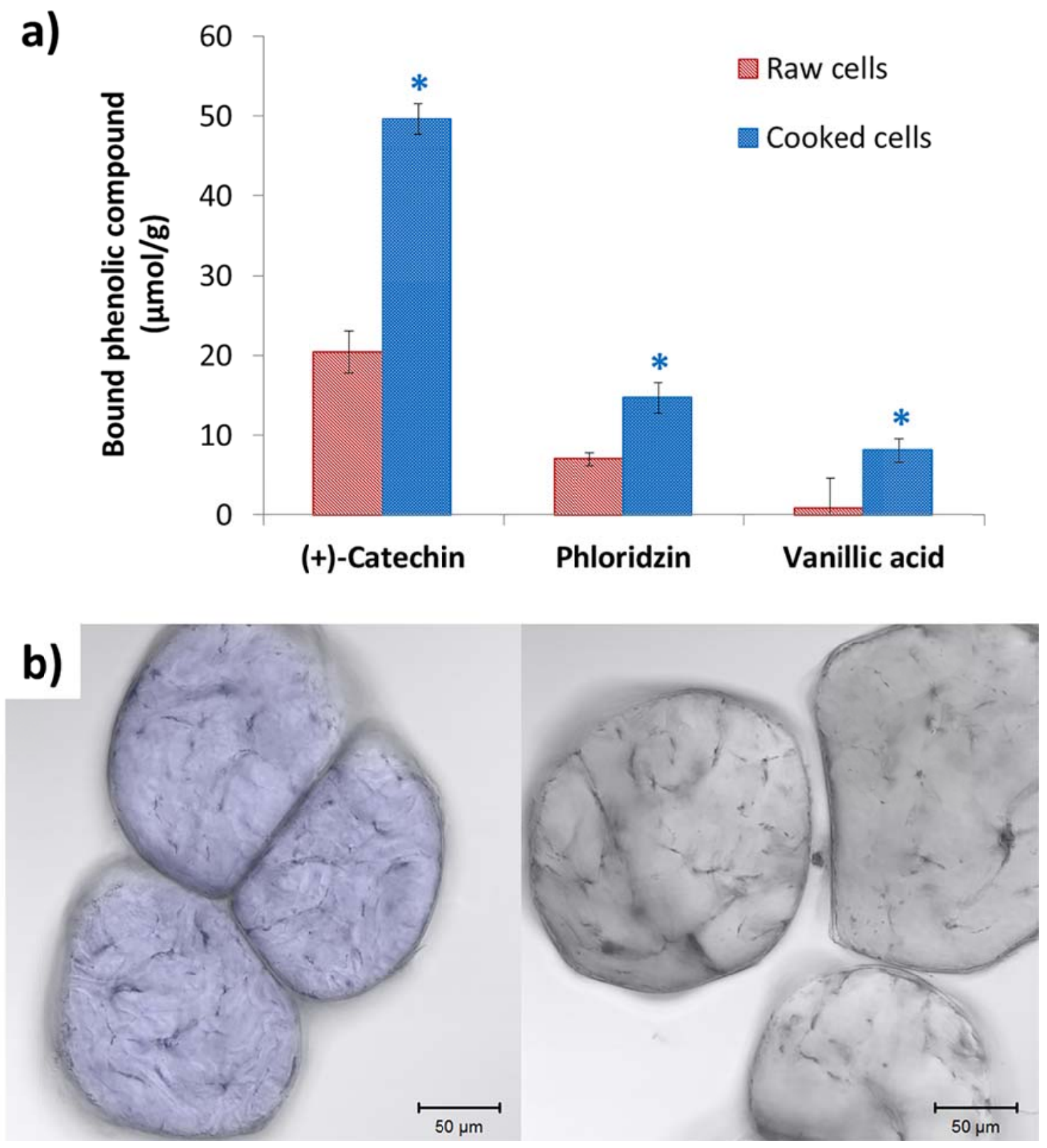

Figure 8. a) Amount of bound phenolic compounds after incubation with raw and cooked potato cells. Experiments were performed at least in triplicate. Error bars represent standard deviations. Asterisks (*) indicate significant differences within the same phenolic compound. b) CLSM images of cooked potato cells after $2 \mathrm{~h}$ contact with $(+)$-catechin (left) and a control in the absence of (+)-catechin (right). Scale bars correspond to $50 \mu \mathrm{m}$. The reader is referred to the web version of the article for colour images. 


\section{Supplementary Material}
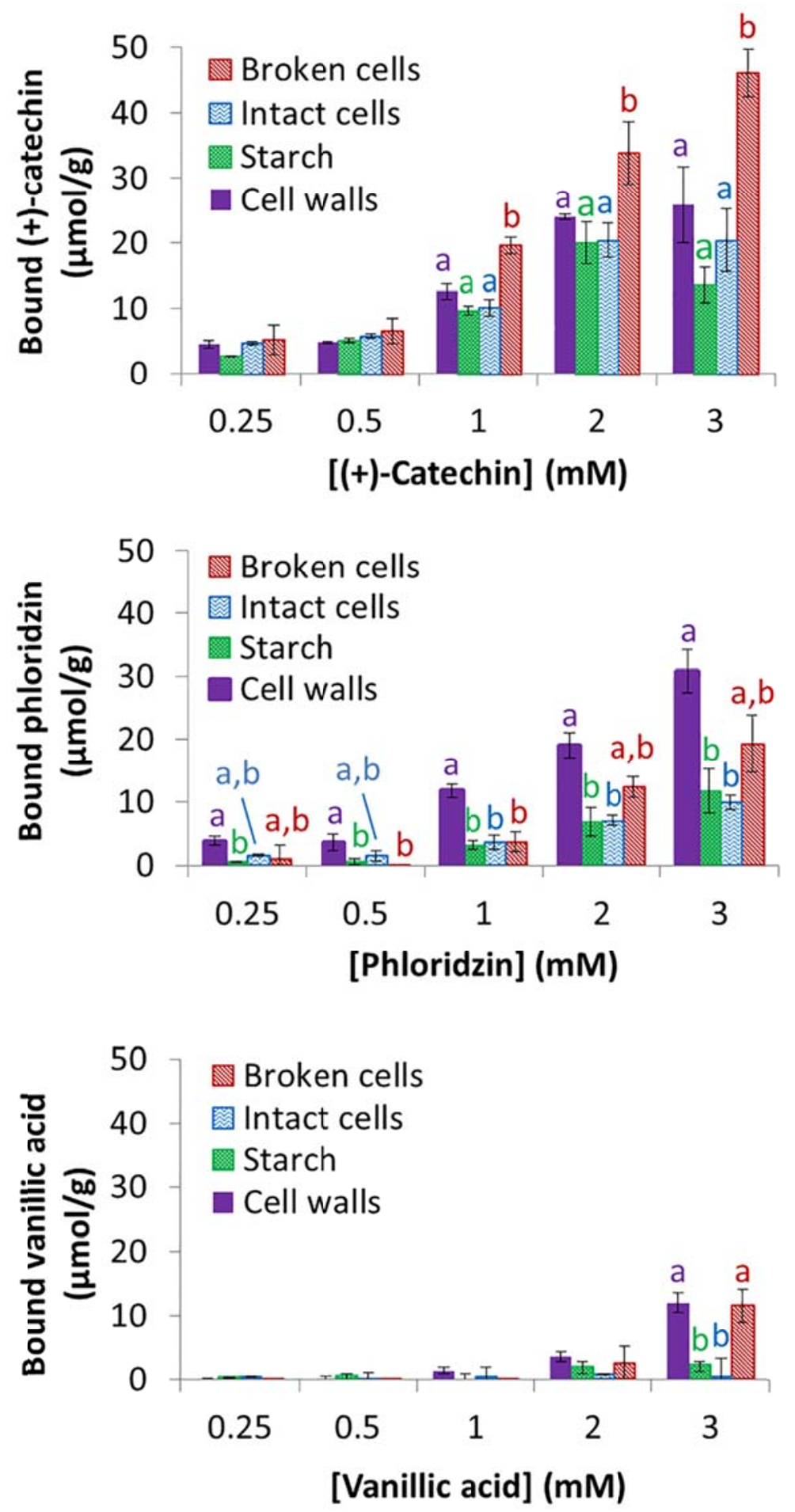

Figure S1. Comparison between the binding capacity of polyphenols to potato cells and cell components at different concentrations after $2 \mathrm{~h}$ incubation. Experiments were performed at least in triplicate. Error bars represent standard deviations. Different letters

$(\mathrm{a}-\mathrm{c})$ within the same series indicate significant differences at $\mathrm{p}<0.05$ among the samples. No letters indicate no significant differences within the series. 